Marquette University

e-Publications@Marquette

Finance Faculty Research and Publications

Finance, Department of

$6-1-2013$

\title{
Catering Driven Substitution in Corporate Payouts
}

Manoj Kulchania

Marquette University, manoj.kulchania@marquette.edu

Accepted version. Journal of Corporate Finance. Vol. 21 (June 2013): 180-195. DOI. (C) 2013 Elsevier. Used with permission.

NOTICE: this is the author's version of a work that was accepted for publication in Journal of Corporate Finance. Changes resulting from the publishing process, such as peer review, editing, corrections, structural formatting, and other quality control mechanisms may not be reflected in this document. Changes may have been made to this work since it was submitted for publication. A definitive version was subsequently published in Journal of Corporate Finance, [VOL 21, (June 2013)]. DOI. 


\title{
Catering Driven Substitution in Corporate Payouts $^{\not x}$
}

\author{
Manoj Kulchania \\ College of Business Administration, \\ Marquette University, Milwaukee, WI 53201, USA \\ manoj.kulchania@marquette.edu
}

Phone: 414-288-1442; Fax: 414-288-5756

Draft: 5th February, 2013

Forthcoming, Journal of Corporate Finance

\footnotetext{
${ }^{*}$ M. Kulchania is the corresponding author of this paper. Email: manoj.kulchania@ marquette.edu,
} 


\begin{abstract}
This paper investigates catering as a motivation for substitution between share repurchases and dividend payments. I hypothesize that firms cater to investor demand by repurchasing shares when investors place a premium on the stock price of firms that repurchase shares, and by paying dividends when investors place a higher value on dividend-paying firms. I propose a proxy to measure the relative preference for repurchases over dividends - the difference premium. Results show that the decision to repurchase shares or to pay dividends depends on this premium. Firms channel higher fractions of the additional payout dollars toward share repurchases when this premium is high. The market reaction to dividend changes is more favorable when firms act in accordance with the catering hypothesis. Overall, I find that catering plays a role in the substitution between repurchases and dividends.

JEL classification: G35
\end{abstract}

Keywords: Repurchases, Payout policy, Catering, Dividends 


\section{Introduction}

Miller and Modigliani (1961) demonstrated that in a world with perfectly efficient and frictionless capital markets, payout policy is irrelevant. In such a world, rational investors do not have any preference for dividends over capital gains. However, subsequent literature has suggested that factors such as taxes, institutional ownership constraints, transaction costs, and the time horizons of investors might affect investor preferences (e.g., Allen et al., 2000; Black and Scholes, 1974; Graham and Kumar, 2006). Baker and Wurgler (2004a) relax the assumption of perfectly efficient capital markets in the Miller and Modigliani model to propose a catering theory of dividends.

Baker and Wurgler $(2004 a, 2004 b)$ find that the managerial decision to pay dividends is driven by investor demand for dividend-paying firms. When investors value dividends, they assign a higher valuation to firms that pay dividends. Managers see this valuation difference and initiate dividends to capture the "premium." Baker and Wurgler calculate their main proxy, the value-weighted dividend premium, as the difference in the logarithm of the value-weighted market-to-book ratio (M/B) of dividend payers and nonpayers. Li and Lie (2005) extend the Baker and Wurgler study to show that dividend catering works not only for initiation of dividends, but also for increases and decreases in the level of dividend payments. $\mathrm{Li}$ and Lie also find that the capital markets reward managers for paying attention to the investor demand for dividends. A different line of literature documents the changing nature of firms that pay dividends (e.g., Fama and French, 2001) and the increasing importance of repurchases in corporate payout policy (e.g., Skinner, 2008). Grullon and Michaely (2002) show that US firms finance their 
share repurchases with funds that otherwise would have been used to increase dividends.

The authors offer the tax-advantaged status of repurchases and a rule change ${ }^{1}$ by the US Securities and Exchange Commission (SEC) as reasons contributing to the substitution of dividend payments with share repurchases. Brown et al. (2007) find evidence supporting a move from repurchases to dividends, specifically in response to a change in tax rates in 2003. I propose catering as a motivation for the observed substitution.

In this paper, I present a catering view of the payout decision. I posit that the choice between repurchases and dividends is a rational managerial response to changing valuations assigned to firms that repurchase shares versus those that pay dividends. Some investors, driven by their time-varying demands, may prefer to hold shares of firms that are repurchasing shares over those that are paying dividends. This demand drives apart the valuations of firms that follow different payout methods, within the limits of arbitrage. Managers rationally cater to this investor demand by repurchasing shares (paying dividends) when investors assign higher valuation to repurchasing (dividendpaying) firms. Baker and Wurgler (2004a) present a catering theory of dividends using similar arguments. They, however, do not discuss share repurchases. I extend the Baker and Wurgler dividend catering theory to share repurchases, while considering the demand for repurchasing and dividend-paying firms together.

\footnotetext{
1 The US Securities and Exchange Commission (SEC) Rule 10b-18 provides a voluntary "safe harbor" from liability for manipulation under Sections 9(a)(2) and 10(b) of the Securities Exchange Act of 1934 (Exchange Act), and Rule 10b-5 under the Exchange Act, when an issuer or its affiliated purchaser bids for or purchases shares of the issuer's common stock in accordance with the Rule 10b-18's manner, timing, price, and volume conditions. These conditions are: (1) on any one day, firms may not purchase more than $25 \%$ of the average daily volume of their own shares during the prior four weeks; (2) firms may not purchase their own shares at the opening and closing one-half hours of trading; (3) firms may not purchase their own shares at a price higher than the last independent bid, or the last reported sale price; and (4) all purchases on a single day must be executed through the same brokerage firm. This rule was adopted in November 1982 and caused an increase in the number of open market repurchase programs adopted (see Grullon and Michaely, 2002; Ikenberry et al., 1995; etc.).
} 
Researchers have documented evidence of catering in other corporate decisions. For example, Baker et al. (2009) show evidence of catering in nominal share prices; Aghion and Stein (2008) find that managers choose between sales growth and profit margins; and Polk and Sapienza (2009) show that mispricing can be driven by levels of investment. To test the catering hypothesis in payout policy, I first calculate the yearly M/B of firms for each year in the period 1971-2010. I then find the yearly difference in the logarithm of the value-weighted $\mathrm{M} / \mathrm{B}$ of repurchasing and non-repurchasing firms. I use this measure as a proxy for the excess valuation that the market assigns to firms that repurchase shares, i.e., the "repurchase premium."2 This proxy is constructed to give a measure comparable to the Baker and Wurgler (2004a) (value-weighted) dividend premium. To capture the relative preference for repurchases over dividends, I define the "difference premium" as the difference between my repurchase premium and the Baker and Wurgler dividend premium. Intuition suggests that firms will find repurchasing shares more attractive, relative to paying dividends, when this difference premium is positive.

I consider the variation in the difference premium proxy over time. Using logit analysis, I find that firms are more likely to repurchase shares (pay dividends) when the difference premium is positive (negative). Hence, the decision to pay dividends or to repurchase shares is based on the relative values of the dividend and the repurchase premium. This finding supports Grullon and Michaely's (2002) substitution hypothesis. If catering explains the observed substitution between repurchases and dividends, then

\footnotetext{
${ }^{2}$ Contrary to some previous mentions in the literature (Peyer and Vermaelen, 2005), the term "repurchase premium" here does not signify the premium that firms have to pay to buy back their own shares (e.g., greenmail).
} 
managers must consider both premiums and decide to substitute one form of payout for the other based on the relative magnitudes of the two premiums. My results hold after controlling for taxes, the 1982 SEC rule change, risk measures (Hoberg and Prabhala, 2009), unobserved firm fixed effects, and other usual firm proxies (e.g., size, capital structure, cash holdings, etc.).

My paper makes several additional contributions to the literature. First, I find that the difference premium explains the residual "propensity to repurchase" after accounting for time-varying firm characteristics, including investment opportunities, profitability, and firm size, using the Fama and French (2001) methodology. The Baker and Wurgler dividend premium cannot account for this repurchasing decision after controlling for risk characteristics (as explained in Hoberg and Prabhala $(2009)^{3}$ ), but the difference premium can.

Second, I find that the repurchase premium is negatively correlated with the Baker and Wurgler dividend premium (correlation coefficient of -0.124 ), reflecting the competing attractiveness of repurchases and dividends. The dividend premium alone, in the presence of control variables for risk, cannot capture the attractiveness of repurchases to dividend payers. This relative attractiveness ties together the dividend and the repurchase premiums and highlights that the dividend premium by itself cannot entirely explain share-repurchasing activity.

Third, I find that firms switch from paying dividends to repurchasing shares when the difference premium is positive. I use the Lintner (1956) dividend model to predict the

3 Hoberg and Prabhala (2009) observe that measures of idiosyncratic and systematic risk are key determinants in the "propensity to pay dividends." They show that the catering explanation of dividend payment loses explanatory power when they control for firm-level risk. However, my results in favor of catering-based substitution between repurchases and dividends hold after controlling for the Hoberg and Prabhala risk variables. 
expected dividend behaviors of firms that repurchase shares and pay dividends, and find a negative relation between dividend forecast errors and the difference premium. In other words, firms pay less than the expected dividend when the repurchase premium is higher than the dividend premium. I also look at changes in total payout and investigate how additional payout dollars are distributed between share repurchases and dividend payments. I find that firms are more likely to channel any increases in total payout toward share repurchases when the difference premium is positive, in line with catering-based substitution. I also look at the investor reaction to announcements of dividend changes and investigate if this reaction is driven by catering. I find that investors react more favorably to announcements of a dividend increase by non-repurchasing firms when firms act in accordance with the predictions of the catering hypothesis. Conversely, when the changes in the difference premium predict that firms should decrease dividends and repurchase shares, and firms follow suit, investors greet these announcements less unfavorably. All of these results confirm that catering plays a role in substitution between dividends and share repurchases.

This is one of the first papers to suggest catering as a potential explanation for the substitution effect found by numerous studies (e.g., Fama and French, 2001; Grullon and Michaely, 2002; Skinner, 2008). The extant literature does not explore how preferences for dividend payments and share repurchases correlate through time and how these correlations relate to firms' payout policies. My paper addresses these questions. Even though dividends and repurchases are competing methods of paying shareholders, the idea of catering based on the relative magnitude of dividend and repurchase premiums is unique to this paper. The results in this paper also shed light on a possible reason why 
firms may announce repurchases in clusters. If the catering view holds, more managers are likely to buy back shares when the repurchase premium is higher than the dividend premium, thereby leading to clustering. These results might also explain the cyclical nature of repurchases. Because the investor demand for shares of repurchasing firms varies, the valuations assigned to firms that repurchase shares also changes. Managers react to this varying demand by changing the supply (affecting the rate of initiations and continuations of repurchases).

In a contemporaneous study, Jiang et al. (2012) also investigate how the catering theory applies to share repurchases. They calculate a repurchase premium proxy based on frequent and infrequent repurchasers and find that firms are more likely to initiate and continue share repurchases when the repurchase premium is high. The authors also find that the fraction of shares repurchased by firms is positively related to the repurchase premium. Their evidence also supports the hypothesis that catering plays a role in the observed substitution between share repurchases and dividend payments. While Jiang et al. control for the Baker and Wurgler dividend premium in their tests, they do not consider the difference between the repurchase and the dividend premiums. The difference premium allows me to see how the relative attractiveness of the two premiums affects two competing methods of paying shareholders, namely share repurchases and dividend payouts. I also investigate how the difference premium affects the distribution of additional payout dollars between share repurchases and dividend payments, the deviations from the "expected" dividend payment behavior based on the Lintner (1956) model, and the abnormal announcement returns surrounding dividend increases and cuts. Overall, my paper focuses on investigating the catering-based substitution and the 
importance of the relative magnitudes of the repurchase and the dividend premium while Jiang et al. confirm more initiation and continuation of repurchases when their repurchase premium is high.

The remainder of the paper is structured as follows. Section 2 explains the main assumptions and intuitive framework for repurchase catering and catering-based substitution. Section 3 explains the data and results of empirical tests. Section 4 concludes.

\section{Payout Catering}

I develop an intuitive framework to analyze the payout decision of firms, along the lines of Baker and Wurgler (2004a). When deciding on their payout policies, managers consider many variables such as investment opportunities, cash holdings, capital structure, agency issues, and signaling implications (e.g., Allen and Michaely, 2003; Brav et al., 2005). Managers face the choice between repurchasing shares and paying dividends, the two most frequently used ways of paying back to shareholders (Allen and Michaely, 2003). In the Miller and Modigliani (1961) perfect capital markets world, this choice has a zero value consequence.

Assume that there are two broad types of investors in this world, category investors and arbitrageurs. Category investors prefer firms that payout to shareholders. These investors are divided into two subcategories: those that repurchase shares and those that pay dividends. In the spirit of Rosch (1978) and Barberis and Shleifer (2003), category investors put firms that repurchase shares and those that pay dividends into separate investment categories. Possible reasons for this categorization are tax clienteles (similar to Black and Scholes, 1974 and Allen et al., 2000), time horizon of investments 
(Graham and Kumar, 2006), the perception that repurchases signal undervaluation (Asquith and Mullins, 1986; Comment and Jarrell, 1991; Vermaelen, 1981), high expected future returns (Massa et al., 2007; Vermaelen, 1981), and even a popular belief that share repurchases are a shareholder-friendly activity (Sanders and Carpenter, 2003; Westphal and Zajac, 2001).

This category-based demand may lead to an irrational expectation about the value of the firm. For example, category investors may categorize because they view nonrepurchasers (or non-dividend payers) as high-growth firms and might judge the future prospects of repurchasers (dividend payers) relative to their current assessment of growth opportunities. Similar cases can be made for other motivations behind categorization. Category investors assign different valuations to the firm: $\mathrm{V}^{\mathrm{R}}$ if the firm repurchases shares, and $\mathrm{V}^{\mathrm{NR}}$ if the firm does not repurchase shares. Similarly, they assign a value of $\mathrm{V}^{\mathrm{D}}$ and $\mathrm{V}^{\mathrm{ND}}$ to firms that pay dividends and those that do not, respectively. They misestimate the mean value but not the distribution around the mean. Typically, $\mathrm{V}^{\mathrm{R}}$ and $\mathrm{V}^{\mathrm{NR}}$ fall on opposite sides of the true fundamental value, just as $\mathrm{V}^{\mathrm{D}}$ and $\mathrm{V}^{\mathrm{ND}}$ do in Baker and Wurgler (2004a).

Arbitragers, in comparison, have rational expectations and know the long-run cost of repurchasing shares and paying dividends. The level of risk aversion among arbitrageurs and category investors might define the limits of arbitrage. With limited arbitrage, the perceptions of category investors cause the relative prices of share repurchasers and dividend payers to differ. In the presence of such pricing differences, managers cater to investor demand (of category investors) by paying out when they think that the net gain to catering is positive. 
When deciding the method of payout, managers look at the premiums (i.e., valuation differences between the different categories) to maximize the firm value. If the observed difference between the repurchase premium and the dividend premium is positive, managers will channel the payout dollars to repurchases. Conversely, if the difference premium is negative, managers pay through dividends. This framework provides the basic intuitive argument for catering-based substitution.

Empirically, this catering hypothesis posits that firms will buy back shares when investor demand for firms that are repurchasing shares is high. More specifically, repurchases (dividends) are positively (negatively) related to the lagged values of the difference premium.

I realize that repurchases and dividends are not perfect substitutes. Dividends tend to be sticky (e.g., Allen et al., 2000; Fama and French, 2002), so it is unreasonable to expect that all dividend-paying firms will cut their payout to zero and start repurchasing simply because the difference premium is positive. Thus, my catering hypothesis posits that firms tune their payout policies to the trends of the difference premium and that the threshold premium for a firm to change its payout policy may differ based on firm characteristics. Some firms, possibly smaller firms without a long history of dividends, might start repurchasing shares when the magnitude of the difference premium is low, but that threshold for a larger firm with a long history of dividends could be higher.

Many studies have considered a "clientele effect" or "catering" as a motivation for many corporate decisions (e.g., Aghion and Stein, 2008; Baker et al., 2009; Polk and Sapienza, 2009). Miller and Modigliani (1961) suggest that dividend clienteles may form based on investor characteristics. Firms that pay higher (lower) dividends might attract 
investors who prefer (dislike) dividend income because of marginal tax rates, age, or income concerns. Graham and Kumar (2006) analyze investor holdings and find that some older investors strongly prefer dividend-paying firms. Shefrin and Statman (1984) argue that "mental accounting" might influence preferences, whereby investors code for gains and losses across investments using prospect theory functions. Shefrin and Thaler (1988) and Thaler and Shefrin (1981) find that regret aversion, self-control problems, and life cycle preferences might also influence investors' preferences for dividends. While clienteles for dividends have been extensively studied (e.g., Allen et al., 2000; Black and Scholes, 1974), clientele effects driving repurchase decisions have not. Baker and Wurgler (2004a) develop a catering theory of dividends, but they do not consider "repurchase catering," or how dividend catering and repurchase catering might be related.

This paper builds on the Baker and Wurgler dividend premium. Because it is quantifiable, I can use it to study the relative attractiveness of dividends and share repurchases, after developing corresponding measures of the repurchase premium.

\section{Data and Empirical Tests}

\subsection{Repurchase premium variables}

Firm-level data for this study are gathered from the Compustat database. The sample period is 1971-2010. To be included in my sample for calculating the premiums, the firm must have the following data in year $t$ (Compustat variable names in parentheses): total assets $(A T)$, stock price (PRCC_F) and shares outstanding $(C S H O)$, income before extraordinary items (IB), interest expense (XINT) [cash] dividends per share by the ex-date $\left(D V P S X_{-} F\right)$, preferred dividends $(D V P)$, and (a) preferred stock liquidating value $(P S T K L)$, (b) preferred stock redemption value $(P S T K R V)$, or (c) 
preferred stock carrying value (PSTK). Firms must also have stockholder equity (SEQ), liabilities $(L T)$, or common equity $(C E Q)$; share price at calendar year end (PRCC_C); and preferred stock par value (PSTK). Following Fama and French (2001), I exclude firms with book equity below $\$ 250,000$ or assets below $\$ 500,000$. I also require that the amount spent on the purchase of common and preferred stock (PRSTKC) be reported. In calculating the total repurchase amount for a firm-year observation, this data item $(P R S T K C)$ is adjusted by decreases in the preferred stock redemption value (PSTKRV) from the year before. As discussed in Stephens and Weisbach (1998) and Dittmar (2000), this adjustment takes care of the conversion of preferred stock into common stock, the retirement of preferred stock, and the retirement or redemption of redeemable preferred stock. If the repurchase amount, after this adjustment, is positive and at least $1 \%$ of the market value of equity, then I consider the firm a repurchaser for the year (otherwise the firm is a non-repurchaser). If a firm has positive dividends per share by ex-date, it is identified as a dividend payer. I exclude utilities and financial firms (Standard Industry Classification (SIC) codes 4900-4949 and 6000-6999) from the sample.

Repurchase Premium is the difference in the logarithm of the M/B weighted by the book-value of assets of firms that are classified as repurchasers and non-repurchasers in a year. M/B is constructed following Fama and French (2001). Dividend Premium is the value-weighted dividend premium from Baker and Wurgler (2004a). I use data from their study through year 2000, and use their methodology to construct this variable for the remainder of the time series. The difference between the repurchase premium and the dividend premium is the Difference Premium. Table 1 shows the values of the payout premiums, and Figure 1 shows these premiums by year. 
Compustat started reporting data on repurchases in 1971. In late 1982, the SEC adopted Rule 10b-18, which had a major impact on repurchase activity (see Grullon and Michaely, 2002 and footnote 1). In 1983, the difference premium rose moderately. The difference between the repurchase and the dividend premiums is close to zero after 1986. This matches the expected outcome of the 1986 Tax Reform Act, which reduced the difference between the capital gains and income tax rates. ${ }^{4}$ The difference premium favors repurchases throughout the early 1990s and falls at the end of 1997. The high difference in premiums for most of the 1990s matches well with the reported rise in repurchases during that time (e.g., Grullon and Michaely, 2002). A drop in the repurchase premium around 2003 likely stems from the Bush tax cuts, ${ }^{5}$ which made repurchasing shares less favorable. ${ }^{6}$ At the onset of the recent financial crisis in 2007 , the difference premium drops below zero. Figure 1 captures some key historic changes that potentially affected the substitution decision of US firms.

Note that a difference premium of $10 \%$ does not imply that a firm that stops dividend payouts and initiates share repurchases will see a $10 \%$ jump in its share price. Firms that follow different payout policies might differ on a number of characteristics,

\footnotetext{
${ }^{4}$ The Tax Reform Act of 1986 lowered the top tax rate from 50\% to 28\%, while the bottom rate was raised from $11 \%$ to $15 \%$ - the first time in the history of the U.S. income tax that the top rate was reduced and the bottom rate was increased concomitantly. In addition, capital gains faced the same tax rate as ordinary income.

5 The Jobs and Growth Tax Relief Reconciliation Act of 2003 (JGTRRA) accelerated the gradual rate reduction and increase in credits passed in the Economic Growth and Tax Relief Reconciliation Act of 2001 (EGTRRA). The maximum tax rate decreases originally scheduled to be phased into effect in 2006 under EGTRRA were retroactively enacted to apply to the 2003 tax year. JGTRRA increased both the percentage rate at which items can be depreciated and the amount a taxpayer may choose to expense. In addition, the capital gains tax decreased from rates of $8 \%, 10 \%$, and $20 \%$ to $5 \%$ and $15 \%$.

6 My data show a drop in the value weighted dividend premium in 2003. When I construct the equallyweighted dividend premium measure, following Baker and Wurgler (2004a), I do not observe this drop. This leads me to believe that firms with high book-value of assets and low M/B joined the group of dividend payers in the wake of JGTRAA, creating this anomaly. See Brown et al. (2007) for a discussion on how incentives, including managerial ownership, played a role in the dividend payment decision of firms around that time.
} 
such as size, maturity, and profitability, which the difference-in-premiums approach does not capture. These firm characteristics, unlike the decision to repurchase shares or pay out dividends, may not be under managerial control. When used here as a proxy, M/B is meant to capture valuation, and the difference premium is meant to capture relative valuation between repurchasers and dividend payers. However, M/B is also used in the literature as a proxy for growth options (e.g., Denis and Osobov, 2005). As such, a disadvantage of this proxy is that it captures growth options of repurchasers relative to dividend payers; therefore, I control for firm-level M/B in pertinent regression.

I create several variables to control for known effects on payout policy decisions (e.g., Fama and French, 2001; Grullon and Michaely, 2002; Hovakimian et al., 2001; Jagannathan et al., 2000; Kahle (2002). When used in regressions as control variables, all independent variables are calculated with a lag of one fiscal year (and represented with a subscript of $t$ - 1 in the tables). When used to control for effects in the same time period, contemporaneous variables are used (and represented with a subscript of $t$ in the tables). LnAssets is the logarithm of total assets. Debt is defined as long-term debt (DLTT) scaled by the book-value of assets. Cash is defined as cash and cash equivalents $(C H E)$ scaled by the book-value of assets. $R O A$ is the return on assets, defined as the operating income $(O I B D P)$ scaled by the book-value of assets. Std. Dev. ROA is the standard deviation of the ROA, calculated over the last three years. Tax is the difference between the highest prevalent rate in income tax over capital gains tax. $F C F$ is the free cash flow, defined as the gross operating income $(O I B D P)$ minus the sum of depreciation $(D P)$, tax payments (TXT), interest expenses (XINT), and dividends scaled by the book-value of assets. Std. Dev. FCF is the standard deviation of the FCF, calculated over the last three years. 
Return is the return on the stock price of the firm over the current fiscal year. Nonoperating Income is the non-operating income before depreciation (NOPI) scaled by the book-value of assets. Repurchase Yield (Dividend Yield) is calculated by scaling the dollar amount of repurchases (dividends) by the market value of equity.

I also create variables to control for risk, as suggested by Hoberg and Prabhala (2009). NYP is the NYSE market capitalization percentile, i.e., the fraction of NYSE firms having equal or smaller capitalization. Idiosyncratic Risk is the standard deviation of residuals from a regression of the firm's daily excess stock returns on the market factor (i.e., the CRSP value-weighted market return less the riskfree rate). One firm-year value of idiosyncratic risk is computed using returns data from one calendar year. Systematic Risk is the standard deviation of the predicted value from the idiosyncratic risk calculation.

\subsection{Firm-level decision to repurchase shares or to pay dividends}

First, I investigate the firm-level decision to repurchase shares or to pay dividends. I test how the difference between the repurchase and the dividend premium affects the payout choice after controlling for firm characteristics. Table 2 shows the results of these tests. Specification 1 shows the result of a logit regression to model the decision to pay dividends using data on all sample firms between 1972 and 2010. The coefficient on the difference premium is negative and significant, suggesting that firms are more likely to pay dividends when the difference premium is negative (i.e., the dividend premium is greater than the repurchase premium). In specification 2, I run a similar logit regression on the decision to repurchase shares. The coefficient on the difference premium is positive and significant, suggesting that firms are more likely to 
repurchase shares when the difference premium is positive (i.e., the repurchase premium is greater than the dividend premium). These results are similar to Jiang et al. (2012) who find that that firms are more (less) likely to repurchase shares when their repurchase (the Baker and Wurgler dividend) premium is high (low).

Grullon and Michaely (2002), Stephens and Weisbach (1998), and others point out the importance of SEC Rule 10b-18 passed in 1982. Repurchases became more prevalent after this rule was enacted. To control for any biases resulting from this rule change, I run a regression (specification 3) to model the decision to repurchase shares using data from 1983 onwards. In specification 4, I run a similar regression for the period 1971-2006, ending just before the onset of the financial crisis of 2007. The results remain unaffected by these time-period choices. Finally, to control for unobserved firm heterogeneity, I run a firm fixed-effects logit regression model (specification 5). The difference premium continues to be positively related to the decision to repurchase shares, ruling out any systematic unobserved firm-level variable driving these results. ${ }^{7}$ The decision to repurchase shares or to pay dividends is affected by the difference premium, after controlling for tax rate differentials between income and capital gains, measures of firm-level risk, the 1982 SEC rule change regarding share repurchase guidelines, the recent US financial crisis, and other unobserved firm fixed effects. This shows strong support for the catering hypothesis, indicating that firms are more likely to

\footnotetext{
7 When running a logit regression with firm fixed effects, if the dependent variable does not change for a firm during the sample period, all observations for that firm are dropped from the test. Hence, the number of observations drops from 85,678 in specification 2 to 54,678 in specification 5 of Table 2 . The 54,678 observations for this specification are for firms that paid dividends and repurchased shares at some time during the sample period.
} 
repurchase shares (pay dividends) when the repurchase premium is greater (smaller) than the dividend premium. ${ }^{8}$

I also perform robustness checks by repeating the logit regressions shown in specifications 1 and 2 of my Table 2 but replacing my difference premium proxy with the Jiang et al. (2012) value-weighted repurchase premium (not shown). I find a significant and negative (positive) coefficient on the Jiang et al. VW repurchase premium proxy when modeling the decision to pay dividends (repurchase shares). I get similar and statistically significant results when I replace the difference premium proxy with my repurchase premium proxy. When I create a proxy similar to that of Jiang et al., using repurchase classification over multiple years, I get results similar to the repurchase premium proxy used in this paper. These results further show that the Jiang et al. repurchase premium proxy and my repurchase premium proxy are related. ${ }^{9}$ Banyi et al. (2008) evaluate the accuracy of multiple share repurchase measures and conclude that the Compustat purchase of common stock, which I use, is a better measure for the actual number of shares repurchased by firms than the number of shares outstanding listed in the Center for Research in Security Prices (CRSP) database, which Jiang et al. use. While doing their robustness checks, Jiang et al. also note that their results hold when they use Compustat-based purchase of common stock as a proxy for share repurchases.

Taken together, these results show that the decision to pay dividends or to repurchase shares is related to the relative magnitude of the two premiums. Firms are

\footnotetext{
8 In unreported results, I also run regressions on all specifications reported in Table 2 with variables to control for time trend and also with dummy variables to control for industry characteristics (using the 48 industry dummies of Fama and French (1997) and two- and three-digit SIC codes). The results are strongly significant in all these cases.

9 In my sample period of 1971-2010, the Jiang et al. unadjusted value-weighted (VW) repurchase premium proxy and my repurchase premium proxy are significantly positively correlated (correlation coefficient of 0.688 with a $p$-value less than .001).
} 
more likely to repurchase shares (pay dividends) when the difference premium is positive (negative). These results show that the Baker and Wurgler dividend premium should be considered relative to the repurchase premium when modeling the decision to repurchase shares or the decision to pay dividends. Prior literature (Grullon and Michaely, 2002; Skinner, 2008; etc.) has discussed firms substituting one form of payout with the other, but this is the first evidence hinting at competing clienteles driving payout decisions. My results show that the relative magnitudes of the two premiums affect the decision to repurchase shares or to pay dividends.

\subsection{Controlling for time-varying firm characteristics}

Fama and French (2001) find that three fundamentals-profitability, investment opportunities, and size - factor into the decision to pay dividends. In this section, I look at the possibility that the difference premium is related to the cross-sectional distribution of payout-relevant characteristics of dividend payers and share repurchasers. For example, suppose that earnings of repurchasing firms increase when the repurchase premium is higher than the dividend premium (i.e., the difference premium is positive). In such a situation, the probability to repurchase shares may be driven by the excess cash (realized from higher earnings) that repurchasers have and not by the difference premium. Specifically, I examine whether the difference premium helps to explain the residual variation in the repurchase decision after controlling directly for sample characteristics, particularly those found to be significant by Fama and French. I include the same variables when I model the repurchase behavior, captured in the following equation:

$\operatorname{Pr}\left(\right.$ Repurchaser $\left._{i t}=1\right)=\operatorname{logit}\left(a+\right.$ bNYP $\left._{i t}+c \frac{M}{B_{i t}}+d \frac{d A}{A_{i t}}+e \frac{E}{A_{i t}}\right)+u_{i t}$ 
NYP is as defined previously. M/B is the market-to-book ratio as defined previously, with the slight modification that here I use the fiscal year-end stock price instead of the calendar year-end stock price. Growth in book assets (dA/A) is calculated as the change in asset size between year $t-1$ and $t$, scaled by assets. Profitability (E/A) is the earnings before extraordinary items $(I B)$ plus interest expenses (XINT) plus income statement deferred taxes $(T X D I)$ divided by the book-value of assets.

This test is conducted in two stages. In the first stage, following Fama and French, I estimate a set of yearly Fama-MacBeth logit regressions (Fama and MacBeth, 1973) from 1972 to 2010 on the decision to repurchase shares, controlling for firm characteristics. The yearly coefficients estimated as a result of the logit regression (and the values of the explanatory variables) are then used to estimate the expected probability of repurchasing shares for each firm. Then, I calculate the prediction errors (actual policy minus predicted policy) for each firm. The error term, $u$, shown in equation (1), thus captures the residual probability of repurchasing shares. I sum the residuals by year and calculate the average error by dividing the summed residual error by the number of firms in the sample for that year $t$. The averaged residual is the yearly "propensity to repurchase," or PTR, after controlling for firm-level variation in size, growth options, and profitability. In the second stage, I see if this average annual residual is driven by the lagged value of the variable of interest, $P_{t-1}$ :

$$
\begin{aligned}
\operatorname{PTR}_{\mathrm{t}} & =\mathrm{f}+\mathrm{gP}_{\mathrm{t}-1}+\mathrm{v}_{\mathrm{t}}, \\
\text { where } \operatorname{PTR}_{\mathrm{t}} & =\frac{1}{\mathrm{~N}} \sum_{\mathrm{i}} \mathrm{u}_{\mathrm{it}}
\end{aligned}
$$


The regression in equation (2) aims to explicitly remove the effect of time-varying characteristics, and the two-stage approach allows the difference premium to explain only the residual variation, after taking firm characteristics into account.

First, I run the above described regressions for all sample firms using data from 1972-2010. Panel A of Table 3 shows results for the second stage of the regression. Specification 1 shows the results when the lagged difference premium is regressed on the propensity to repurchase. The coefficient on the difference premium is positive and significant, indicating that the difference premium can explain the residual propensity to repurchase shares, after controlling for size, M/B, and profitability. Specification 2 shows the results when the propensity to repurchase is regressed on the lagged value of the Baker and Wurgler dividend premium variable. The coefficient on the dividend premium variable is negative, in line with the Grullon and Michaely (2002) substitution hypothesis, and the Baker and Wurgler (2004a) finding that the "propensity to pay dividends" is positively related to the dividend premium.

Hoberg and Prabhala (2009) find that the Baker and Wurgler dividend premium cannot explain the propensity to pay dividends in the presence of measures controlling for the firm-level idiosyncratic and systematic risks. To see how the difference premium behaves in the presence of these risk measures, I change the first stage of the above described regression to include terms for idiosyncratic and systematic risks (in addition to the four variables originally used to capture size, growth options, and profitability), as described in Hoberg and Prabhala. Results (in specification 3) show that including these risk measures in the first stage of the regression does not change the sign or significance of the difference premium in the second-stage regression. However, in line with the 
Hoberg and Prabhala finding, adding the risk measures in the first stage of the regression results in the dividend premium variable losing its significance in the second stage of the regression (see specification 4). This shows that the difference premium has explanatory power in predicting the probability of repurchasing shares after controlling for firm-level variation in size, growth options, profitability, and risk measures. The Hoberg and Prabhala risk variables soak up the significance of the dividend premium in explaining the decision to pay dividends, but the relative attractiveness of dividends over repurchases (captured by the difference premium variable) still has explanatory power in the decision to repurchase shares. This may be driven by the nature of the repurchase decision timing (decided after investment decisions, as suggested by the Brav et al. (2005) survey) or the inherent flexibility that share repurchases offer (compared with that of dividend payments, which tend to be "sticky").

After looking at the repurchasing decision of all firms in the sample, I model the repurchasing decision of dividend-paying firms. I restrict my sample (for the FamaMacBeth regressions) to only the dividend-paying firms. I use the method described earlier to calculate the probability that the dividend-paying firms repurchase shares, and then I calculate the residual propensity to repurchase shares. I then test if the lagged values of the difference premium can explain variations in the propensity to repurchase shares by dividend-paying firms. Panel B of Table 3 shows the corresponding results. The dividend-paying firms are more likely to repurchase shares when the lagged value of the difference premium is positive. Controlling for the Hoberg and Prabhala risk measures does not decrease the significance level of this result. Interestingly, the Baker 
and Wurgler dividend premium does not significantly explain the repurchasing choice of dividend-paying firms.

These results show that the difference premium can explain share repurchasing activity after controlling for the time-varying firm characteristics, including the Hoberg and Prabhala (2009) risk variables. The main results hold in the broad universe of Compustat firms and in a subsample of dividend-paying firms, demonstrating that the difference premium has explanatory power beyond that of the dividend premium alone. The difference premium captures the relative attractiveness of repurchases over dividends, while the dividend premium captures the attractiveness of dividends alone. ${ }^{10,11}$ 3.4 Deviation from the expected dividend payout and the role of catering in substitution

Next, I evaluate the evidence related to firm-level substitution of repurchases for dividends to determine if catering plays a role in this substitution. I use a modified Lintner (1956) analysis of how firms determine their dividend policy. In the spirit of Skinner (2008), I separate firms that have repurchased shares and paid dividends in at least half of the years in my sample period. Using my sample period of 1971-2010, I separate firms that exist for the entire period and have paid dividends and repurchased

10 Because M/B is also sometimes used as a proxy for investment opportunities, Fama and French (2001) also estimate a model for the first-stage regression without M/B in the specification for the Fama-MacBeth logit regression. When I replicate that procedure (and drop M/B from equation 1 while estimating coefficients for the annual logit regressions), my results are unchanged. Also, for the sake of brevity, I show only results for the propensity to repurchase (PTR), but when I model the corresponding propensity to pay dividends, I get similar results. The coefficient on the lagged value of the dividend premium variable is positive (as expected from the competing nature of dividends and repurchases for the same payout dollars). The coefficient on the lagged value of the difference premium is negative and significant at the $10 \%$ level.

${ }^{11}$ Results are robust to changing the specification in equation 1 to add variables for the one-year growth in sales (between year $t-1$ and $t$ ) of the firm, the logarithm of one plus the firm's age in the CRSP database, the logarithm of the standard deviation of the firm's daily stock returns (over the year $t$ ), and the current retained earnings (divided by assets), as in Grullon et al. (2011). When the "propensity to repurchase" calculated from the first stage regression with the above described control variables (in addition to the four Fama-French variables and the variables for systematic and idiosyncratic risk) is regressed on the lagged difference premium, the coefficient on the difference premium variable is positive and significant. 
shares in at least 20 of these 40 years. This helps narrow my sample to a probable list of firms that are equally likely to pay dividends or repurchase shares. I do not require that a firm does both in the same year. I also do not impose any restrictions on when the payout occurred — in the early or the late part of the sample period—or whether they occurred in consecutive years or not. Using the Lintner model, I estimate the expected dividend payment for a firm based on its past dividend payment behavior. I then calculate deviations from the expected dividend payment by comparing the expected and the actual dividend payment of a firm. The deviation from the expected dividend payout is captured by the residual dividend error, defined as:

$$
\text { Error }_{i, t}=\left[\Delta D I V_{i, t}-\left(\beta_{i, 1}+\beta_{i, 2} E_{i} A R N_{i, t}+\beta_{i, 3} D I V_{i, t-1}\right)\right] / M V_{i, t-1}
$$

For a firm $i, \triangle D I V_{i, t}$ is the actual change in dividends, and $E A R N_{i, t}$ captures earnings in year $t . M V_{i, t-1}$ is the market value of equity for firm $i$ in year $t-1$. The $\beta$ coefficients are estimated for each firm individually, using data from 1971-1990 (roughly half the sample period). These parameter estimates are then used to calculate the residual dividend error for the same firms during 1991-2010 (roughly the second half of the sample period). ${ }^{12}$ This Error captures the difference between the actual and the predicted dividend change for a firm in a given year, scaled by the market value of equity. I regress this residual dividend error on firm characteristics to find out what causes firms to deviate from the expected dividend payout behavior. Following Grullon and Michaely (2002), I use debt, non-operating income, ROA, the repurchase yield, and the standard deviation of ROA as control variables. The substitution hypothesis predicts that if firms are substituting funds

12 At the suggestion of the referee, I repeated the same test by gathering a sample of firms that exist only for the entire estimation period 1971-1990 (and may or may not be missing from the second half of the time period, i.e., 1991-2010). For this robustness check, I also drop any extreme residual dividend error (absolute value greater than 5\%). Results supporting catering-based substitution are also significant in this bigger sample. 
to be used for dividends with repurchases, the residual dividend error will be negatively related to the repurchase yield. If catering plays a role in this substitution, the difference premium should be significant in explaining the residual dividend error. Table 4 shows these results.

Results in specification 1 support the Grullon and Michaely (2002) substitution hypothesis. The negative and significant relation between the residual dividend error and the repurchase yield suggests that firms repurchase more shares when the actual dividend is lower than the expected dividend. The substitution result holds when the Hoberg and Prabhala (2009) risk variables are introduced in specification 2. The negative sign on the repurchase yield persists when I introduce the difference premium in specification 3 . The coefficient on the difference premium is also negative and significant, showing that the actual dividend is lower than the predicted dividend when the difference premium is positive. This supports a catering-based substitution.

Overall, this result supports the view that funds that were to be used to pay dividends are instead being used to repurchase shares when the difference premium is positive. Firms substitute repurchases for dividends in line with predictions of the catering hypothesis. The negative relation between the difference premium and the residual dividend error, similar to the negative relation between the repurchase yield and the residual dividend error, shows that catering plays a role in the previously documented (Grullon and Michaely, 2002) substitution.

\subsection{Distribution of net payout between share repurchases and dividend payments}

Recent evidence suggests that looking at total cash payout rather than any form of

payout alone (e.g., Boudoukh et al., 2007; Grullon et al., 2011) might be more 
appropriate. I next investigate how the difference premium affects the distribution of total payout between share repurchases and dividend payments. I calculate the Total Payout, the sum of dividends and share repurchases, for a firm as well as the changes in total payout compared to the previous year. Similarly, I also determine the changes in dividend payments and the changes in shares repurchases for a firm. I then calculate the fraction of the change in total payout that goes to incremental share buyback, defined as the change in share repurchase divided by the change in total payout. Intuitively, this ratio represents the fraction of an additional dollar of total payout used toward share repurchases. A positive fractional change in this measure results in an increase in share repurchases when the total payout increases. I investigate if the difference premium can explain how firms allocate additional payout dollars toward repurchases. Table 5 shows the results of these ordinary least squares (OLS) and tobit regressions.

After controlling for size, M/B, change in ROA, risk measures, I find that the OLS regression coefficient on the lagged difference premium is positive and significant. ${ }^{13}$ This indicates that firms use a higher fraction of additional payout dollars toward repurchases when the difference premium is positive. Results are strong for the entire sample period and for the period after the 1982 SEC rule change (shown in specifications 1 and 2, respectively). I also run a tobit regression to explain the fraction of the change in

\footnotetext{
${ }^{13}$ The negative coefficient on the Tax variable is a little puzzling in these regressions. Considering that the Tax variable is defined as the difference between capital gains and the ordinary income tax rates, the negative sign seems to indicate that firms channel additional payout toward repurchases when the rate of the ordinary income tax is higher than that of the capital gains tax. In unreported results, I find that this sign is sensitive to specific time periods. When the data for the OLS and tobit regressions is restricted to years after the Tax Reform Act of 1986, the sign on the Tax variable is positive and significant (and the sign on the Difference Premium variable remains positive and significant). Thus, the negative sign on the Tax variable appears to be driven by the higher-than-expected allocation of incremental payout dollars toward dividends between 1972 and 1986, in spite of the unfavorable tax treatment of dividends. Black (1976), and others, have talked specifically about this puzzling phenomenon of firms preferring to pay dividends in spite of tax disadvantages, and named it the "Dividend Puzzle."
} 
total payout that goes toward share repurchases. Results in specification 3 show that a higher fraction of the change in total payout is channeled toward share repurchases when the difference premium is positive.

Jiang et al. (2012) look at the fraction of shares repurchased by firms and find results confirming the catering hypothesis. They find that firms repurchase more shares when the repurchase (dividend) premium is high (low). While my results provide insight into how the incremental payout dollars are divided between share repurchases and dividend payments, they find that the overall fraction of shares repurchased increases with the repurchase premium and decreases with the dividend premium.

These results further show that catering plays a significant role in how firms decide to adjust the fraction of share repurchases in their overall payout policies. A higher fraction of the incremental dollar of payout goes toward share repurchases when investors value share repurchases more than dividend payments. This notion of dividing the total payout with an eye toward the difference premium further supports catering-based substitution between dividends and share repurchases.

\subsection{Market reaction to substitution in line with catering incentives}

Presumably, managers cater to the investor demand for a particular payout in an effort to capture the valuation premium. A related question that remains unanswered is how investors perceive the managerial action of catering. All else equal, if managers rationally cater to appease the investor demand for a specific payout, any substitution in line with catering should be viewed more favorably by investors. Specifically, if the catering view holds, it is likely that the stock market reaction to announcements leading to dividend decreases would be significantly less negative when firms decrease dividends 
and repurchase shares in response to catering incentives. If substitution is not driven by catering, then the market reaction to dividend decreases and share repurchases would not be driven by the difference premium.

As Grullon and Michaely (2002) point out, testing such a hypothesis is not simple. It is rare for firms to simultaneously announce a share repurchase and a dividend reduction because it could signal to the Internal Revenue Service (IRS) that the announced repurchase is a perfect substitute for a dividend cut. As a way to get around this problem, Grullon and Michaely look at announcements of dividend decreases and see how the prior share-repurchasing activity of firms explains the market response to such announcements. Research shows that stock market reaction to dividend decreases is largely negative and to dividend increases is largely positive (e.g., Asquith and Mullins, 1986; Healy and Palepu, 1988). However, in line with substitution hypothesis, Grullon and Michaely find that the market reaction to announcements of dividend decreases are less negative when such announcements are made by share-repurchasing firms. I augment the Grullon and Michaely approach by examining dividend changes_-increases as well as decreases - to see how the market reacts to substitution in the face of changing catering incentives. Intuition suggests that investors will greet firms more favorably when they follow investors' wishes (and cater to their demand for a specific payout) and less favorably when firms do not.

To test this, I collect a sample of all announcements of changes in cash dividends between 1972 and 2010, from the CRSP database. We know (e.g., Brav et al., 2005) that investors view large dividend changes (decreases as well as increases) as very strong signals. Because dividends and repurchases are not perfect substitutes (e.g., Lee and Rui, 
2007), it is unlikely that the market reaction to large decreases (increases) in dividends will be anything but negative (positive). Expecting the predictably strong reaction at the extremes, I turn to smaller changes in dividends. I look at announcements of changes in quarterly cash dividends that resulted in a dividend reduction or increase between 5 and $25 \%$. For this sample of firms, I calculate the three-day cumulative abnormal return (CAR), using the event-time window of -1 to +1 trading days around the announcement of the dividend change. CARs are calculated using the standard event-study methodology (e.g., Brown and Warner, 1980). The parameters of the market model are estimated over 255 trading days, ending 46 days prior to the announcement, using the CRSP valueweighted index as the market portfolio and requiring a minimum of 100 trading days over the estimation window.

I separate the announcements of dividend changes into two bins: one containing the announcements that led to increases in dividends and the other containing the announcements that led to decreases in dividends. I match the changes in dividends to the repurchasing activity of the firm. I also measure the change in the difference premium leading up to the announcement of the dividend change. Then, I classify the results based on how the market reacts to two predictions of the catering hypothesis. I look at a case where the catering hypothesis predicts a move toward dividends and away from repurchases (i.e., the difference premium decreases) and another where the catering hypothesis predicts a move toward repurchases and away from dividends (i.e., the difference premium increases). My results support the idea that the market rewards firms that consider investor demand for a specific type of payout. 
Table 6 shows the mean and median CARs around announcements of dividend changes (between 5 and $25 \%$ of the previous year's dividend) by firms in the CRSP database between 1972 and 2010. The left panel includes announcements of dividend increases when the difference premium decreased. If the catering hypothesis holds, a decrease in the difference premium suggests that firms should increase dividends and move away from repurchases. Within this group, I examine how the repurchasing activity of the firms during the prior fiscal year changes the market response. Separating firms on repurchasing activity makes it easier to examine the Grullon and Michaely (2002) substitution relative to the catering hypothesis. For the cases when the difference premium decreased, the announcement of a dividend increase by non-repurchasing firms is greeted with a statistically significant average CAR of $1.052 \%$. In the same situation, firms that did not follow the catering prescription and repurchased shares before announcing dividend increases see a positive but lower CAR of $0.893 \%$. The difference in market reaction between the repurchasing and non-repurchasing firms in this group is negative and significant. This supports the prediction of the catering hypothesis that investors greet firms more favorably when they pay attention to investor demands.

The right panel of Table 6 includes firms that announced reductions in dividend payments when the difference premium increased. Catering hypothesis predicts that increases in the difference premium will be met with more repurchases and decreases in dividend payments. I find that announcements of dividend decreases by repurchasing firms under this situation are met with a negative but statistically insignificant CAR ($0.103 \%)$. In the same situation, announcements of dividend decreases by nonrepurchasing firms see a more negative $(-0.705 \%)$ and statistically significant CAR. On 
average, announcements of dividend decreases in line with catering predictions result in a statistically significant difference of $0.602 \%$ in CAR. I find similar results when comparing the median CARs.

To further control for other factors that could affect the market reaction to dividend changes, I repeat the tests in a multivariate setting. Table 7 shows the results of these tests. I use Change percent - the absolute value of the announced percentage change in dividend-as a control for the size of the dividend change. Consistent with substitution, I find that the announcements of dividend decreases are met with more favorable CARs when the firm also repurchases shares. When I add the lagged value of the difference premium to the regression (specification 3), I find a positive and significant coefficient on the difference premium variable. This indicates that the market reaction to a dividend decrease is more positive when the difference premium is positive. The market reaction to dividend increases indicates that the CARs are higher when the firm did not repurchase shares and also when the difference premium is negative. These results further support the catering hypothesis and show that catering plays a role in the substitution between dividends and repurchases. Investors react more favorably to announcements of dividend changes when these announcements are in line with the predictions of the catering hypothesis.

Overall, the univariate and multivariate results for announcements of changes in dividends show that the market reacts positively to dividend increases and negatively to dividend decreases. Clearly, there is more to the announcement of dividend changes than catering alone. However, within this framework, investors react more favorably when the firms act in line with the predictions of the catering hypothesis. When the difference 
premium is negative and firms announce a decrease in dividends and repurchase shares, investors react less unfavorably.

\section{Conclusion}

Catering hypothesis posits that managers rationally cater to investor demand. When applied more specifically to payout policy, this hypothesis predicts that managers are more likely to repurchase shares when the premium investors place on shares of repurchasing firms is higher than the premium they place on shares of dividend-paying firms. I propose a proxy for measuring the attractiveness of repurchases - the repurchase premium. I relate this to the dividend premium (Baker and Wurgler, 2004a) and also propose a proxy to measure the attractiveness of repurchases over dividends-the difference premium. Using data from 1971-2010, I find that firms are more likely to repurchase shares (pay dividends) when the lagged value of the difference premium is positive (negative). Results support the catering hypothesis after controlling for firm characteristics, the differences in tax rates between income and capital gains, measures of firm-level risk, unobserved firm fixed effects, the 1982 SEC rule change that made repurchases more attractive, and the recent financial crisis.

A contemporaneous study by Jiang et al. (2012) finds that firms are more likely to initiate and continue share repurchases when investors value firms that frequently repurchase shares more than those that do not. Jiang et al. also find that the fraction of shares repurchased increases with their repurchase premium and decreases with the Baker and Wurgler dividend premium. I find that the difference premium can explain the propensity to repurchase shares, after controlling for the time-varying firm characteristics studied by Fama and French (2001) and the risk variables studied by Hoberg and 
Prabhala (2009). The difference premium can also explain the repurchasing activity of dividend-paying firms. I find catering incentives to be related to deviations from the predicted payout behavior of firms (modeled using the Lintner (1956) approach). Evidence suggests that firms deviate from the predicted dividend payment and repurchase more shares when the difference premium is positive. My results also indicate that firms channel a higher fraction of the additional payout dollars toward share repurchases when the difference premium is positive. These results together support the role of catering in the well-documented substitution of repurchases for dividends (Grullon and Michaely, 2002).

Investors react positively to the news of dividend increases and negatively to the news of dividend decreases, irrespective of the firm's share-repurchasing activity. This fact underlines that dividends and repurchases are not perfect substitutes. However, investors treat dividend decreases by repurchasing firms more favorably when managers pay attention to the investor demand for repurchases. Overall, my results show that the decision to repurchase shares or to pay dividends is driven by the relative magnitude of the dividend and repurchase premiums. This relative attractiveness of dividends and repurchases indicates a role for catering in explaining the substitution between repurchases and dividends. 


\section{Acknowledgements:}

I am grateful to Oya Altinkilic, Malcolm Baker (FMA Doctoral Student Consortium discussant), Leonce Bargeron, Tom Boulton, Marcus Braga-Alves, Jesse Ellis, Stuart Gillan (editor), Vidhan Goyal, Sonia Gupta, Ken Lehn, Sara Moeller, Marios Panayides, Sarah Peck, Anthony Pennington-Cross, Kuldeep Shastri, Shawn Thomas, Chad Zutter, an anonymous referee, and seminar participants at the 2008 FMA Doctoral Student Consortium, Fairfield University, Florida Atlantic University, Marquette University, and the University of Pittsburgh for helpful comments and suggestions on this and a prior version of this paper (entitled "Do firms cater to investor demand when repurchasing?"). The usual disclaimer applies. 


\section{References:}

Aghion, P., Stein, J., 2008. Growth vs. margins: Destabilizing consequences of giving the stock market what it wants. J. Financ. 63, 1025-1058.

Allen, F., Bernardo, A.E., Welch, I., 2000. A theory of dividends based on tax clienteles. J. Financ. 55, 2499-2536.

Allen, F., Michaely, R., 2003. Payout policy, in: Constantinides, G., Harris, M., Stulz, R. (Eds.), Handbooks of Economics, North-Holland, pp. 337-429.

Asquith, P., Mullins, D., 1986. Signaling with dividends, stock repurchases, and equity issues. Financ. Manage. 15, 27-44.

Baker, M., Greenwood, R., Wurgler, J., 2009. Catering through nominal share prices. J. Financ. 64, 2559-2590.

Baker, M., Wurgler, J., 2004a. A catering theory of dividends. J. Financ. 59, 1125-1165.

Baker, M., Wurgler, J., 2004b. Appearing and disappearing dividends: The link to catering incentives. J. Financ. Econ. 73, 271-288.

Banyi, M.L., Dyl, E.A., Kahle, K.M., 2008. Errors in estimating share repurchases. J. Corp. Financ. 14, 460-474.

Barberis, N., Shleifer, A., 2003. Style investing. J. Financ. Econ. 68, 161-199.

Black, F., 1976. The dividend puzzle. J. Portfolio Manage. 2, 5-8

Black, F., Scholes, M.S., 1974. The effects of dividend yields and dividend policy on common stock prices and returns. J. Financ. Econ. 1, 1-22.

Boudoukh, J., Michaely, R., Richardson, M.P., Roberts, M.R., 2007. On the importance of measuring payout yield: Implications for empirical asset pricing J. Financ. 62, 877915.

Brav, A., Graham, J., Harvey, C., Michaely, R., 2005. Payout policy in the 21 st century. J. Financ. Econ. 77, 483-527.

Brown, J.R., Liang, N., Weisbenner, S., 2007. Executive financial incentives and payout policy: Firm responses to 2003 dividend tax cut. J. Financ. 62, 1935-1965.

Brown, S.J., Warner, J.B., 1980. Measuring security price performance. J. Financ. Econ. 8, 205-258. 
Comment, R., Jarrell, G., 1991. The relative signaling power of dutch-auction and fixedprice self-tender offers and open-market share repurchases. J. Financ. 46, 1243-1271.

Denis, D.J., Osobov, I., 2005. Why do firms pay dividends? International evidence on the determinants of dividend policy. J. Financ. Econ. 89, 62-82.

Dittmar, A., 2000. Why do firms repurchase stock? J. Bus. 73, 331-355.

Fama, E.F., French, K.R., 1997. Industry cost of equity. J. Financ. Econ. 43, 153-193.

Fama, E.F., French, K.R., 2001. Disappearing dividends: Changing firm characteristics or lower propensity to pay? J. Financ. Econ. 60, 3-44.

Fama, E.F., French, K.R., 2002. Testing trade-off and pecking order predictions about dividends and debt. Rev. Financ. Stud. 15, 1-33.

Fama, E.F., MacBeth, J., 1973. Risk, return, and equilibrium: Empirical tests. J. Polit. Econ. 71, 607-636.

Graham, J., Kumar, A., 2006. Do dividend clienteles exist? Evidence on dividend preferences of retail investors. J. Financ. 61, 1305-1366.

Grullon, G., Michaely, R., 2002. Dividends, share repurchases, and the substitution hypothesis. J. Financ. 57, 1649-1684.

Grullon, G., Paye, B., Underwood, S., Weston, J.P., 2011. Has the propensity to pay out declined? J. Financ. Quant. Anal. 46, 1-24.

Healy, P.M., Palepu, K., 1988. Earnings information conveyed by dividend initiations and omissions. J. Financ. Econ. 21, 149-175.

Hoberg, G., Prabhala, N.R., 2009. Disappearing dividends, catering, and risk. Rev. Financ. Stud. 22, 79-116.

Hovakimian, A., Opler, T.C., Titman, S., 2001. The debt-equity choice: An analysis of issuing firms. J. Financ. Quant. Anal. 36, 1-24.

Ikenberry, D., Lakonishok, J., Vermaelen, T., 1995. Market underreaction to open market share repurchases. J. Financ. Econ. 39, 181-208.

Jagannathan, M., Stephens, C.P., Weisbach, M.S., 2000. Financial flexibility and the choice between dividends and stock repurchases. J. Financ. Econ. 57, 355-384.

Jiang, Z., Kim, K.A., Lie, E., Yang, S., 2012. Share repurchases, catering, and dividend substitution. Working paper, Renmin University of China. Available at http://www.ccfr.org.cn/cicf2012/papers/20120128105339.pdf 
Kahle, K.M., 2002. When a buyback isn't a buyback: Open market repurchases and employee options. J. Financ. Econ. 63, 235-261.

Lee, B., Rui, O.M., 2007. Time series behavior of share repurchases and dividends. J. Financ. Quant. Anal. 42, 119-142.

Li, E., Lie, W., 2005. Dividend changes and catering incentives. J. Financ. Econ. 80, 293-308.

Lintner, J., 1956. Distribution of incomes of corporations among dividends, retained earnings, and taxes. Am. Econ. Rev. 46, 97-113.

Massa, M., Rehman, Z., Vermaelen, T., 2007. Mimicking repurchases. J. Financ. Econ. 84, 624-666.

Miller, M.H., Modigliani, F., 1961. Dividend policy, growth and valuation of shares. J. Bus. 34, 411-433.

Peyer, U., Vermaelen, T., 2005. The many facets of privately negotiated repurchases. J. Financ. Econ. 75, 361-395.

Polk, C., Sapienza, P., 2009. The stock market and investment: A test of catering theory. Rev. Financ. Stud. 22, 187-217.

Rosch, E., 1978. Principles of categorization, in: Rosch, E., Lloyd, B.B. (Eds.), Cognition and Categorization. Lawrence Erlbaum Associates, Hillsdale, NJ, pp. 27-48.

Sanders, W.G., Carpenter, M.A., 2003. Strategic satisficing-a behavioral agency perspective on stock repurchase program announcements. Acad. Manage. J. 46,160-178.

Shefrin, H.M., Statman, M., 1984. Explaining investor preference for cash dividends. J. Financ. Econ. 13, 253-282.

Shefrin, M., Thaler, R.H., 1988. The behavioral life-cycle hypothesis. Econ. Inq. 26, 609-643.

Shleifer, A., 2000. Inefficient Markets: An Introduction to Behavioral Finance. Oxford University Press, Oxford, UK.

Skinner, D.J., 2008. The evolving relation between earnings, dividends, and stock repurchases. J. Financ. Econ. 87, 582-609.

Stephens, C.P., Weisbach, M., 1998. Actual share reacquisitions in open market repurchase programs. J. Financ. 53, 313-334. 
Thaler, R.H., Shefrin, H.M., 1981. An economic theory of self-control. J. Polit. Econ. 89, 392-406.

Vermaelen, T., 1981. Common stock repurchases and market signaling: An empirical study. J. Financ. Econ. 9, 139-183.

Westphal, J.D., Zajac, E.J., 2001. Explaining institutional decoupling: The case of stock repurchase programs. Admin. Sci. Quart. 46, 202-228. 


\section{Figures and Tables:}

\section{Figure 1: Payout Premiums and the Difference Premium}

This figure shows the yearly values of the premiums from 1971 to 2010. Repurchasers are firms that have repurchased shares (as indicated by Purchase of Common and Preferred Stock (Compustat data PRSTKC) after adjustments to the decrease in Preferred Stock Redemption Value (PSTKRV) from the year before) worth more than $1 \%$ of their market value of equity. Market value of equity is calculated as the per-share price at the end of the calendar year (PRCC_C) times shares outstanding (CSHO). Non-repurchasers are firms in the sample that are not classified as Repurchasers. Repurchase Premium is the natural logarithm of the value-weighted market-to-book (M/B) ratio for repurchasers minus the natural logarithm of the value-weighted M/B for non-repurchasers. Book-value of assets $(A T)$ is used as the weight in calculating the value-weighted measures. M/B is defined as in Fama and French (2001). Dividend Premium is the value-weighted dividend premium (as defined in Baker and Wurgler, 2004a). Data for the dividend premium until 2000 are as given in the Baker and Wurgler study, and data from 2001-2010 are calculated using the method described therein. Difference Premium is defined as the repurchase premium minus the dividend premium. The dotted line, the dashed line, and the solid line show the Repurchase Premium, the Dividend Premium, and the Difference Premium, respectively. The horizontal axis represents year.

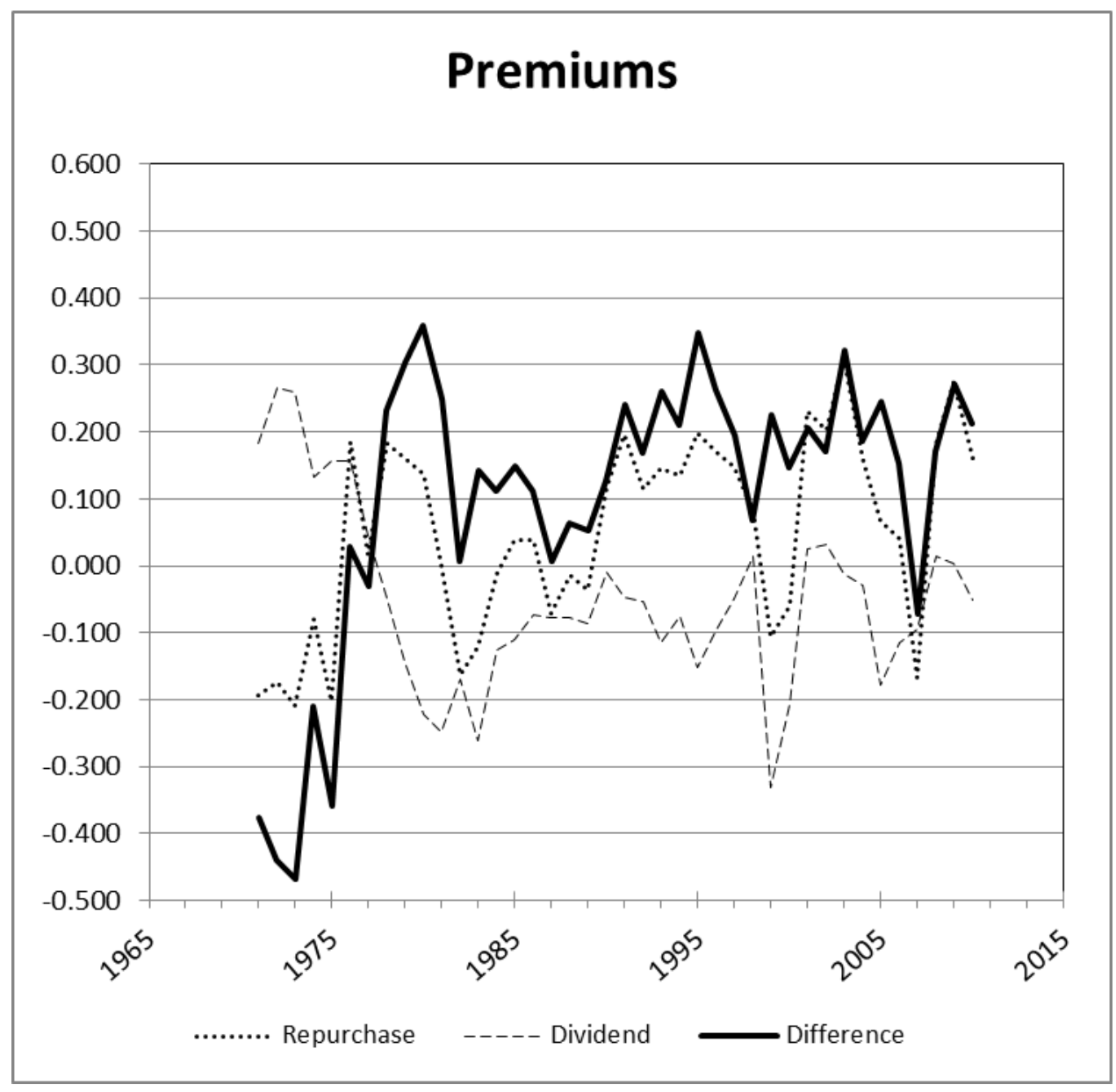


Table 1: Yearly value of the premiums

This table shows the yearly values of the Repurchase Premium, the Dividend Premium, and the Difference Premium from 1971 to 2010. Means and standard deviations for the premiums are also shown.

\begin{tabular}{|c|c|c|c|}
\hline Year & $\begin{array}{c}\text { Repurchase } \\
\text { Premium }\end{array}$ & $\begin{array}{l}\text { Dividend } \\
\text { Premium }\end{array}$ & $\begin{array}{c}\text { Difference } \\
\text { Premium }\end{array}$ \\
\hline 1971 & -0.193 & 0.182 & -0.375 \\
\hline 1972 & -0.174 & 0.266 & -0.440 \\
\hline 1973 & -0.209 & 0.259 & -0.468 \\
\hline 1974 & -0.079 & 0.132 & -0.211 \\
\hline 1975 & -0.202 & 0.156 & -0.358 \\
\hline 1976 & 0.184 & 0.156 & 0.028 \\
\hline 1977 & 0.016 & 0.046 & -0.030 \\
\hline 1978 & 0.182 & -0.050 & 0.232 \\
\hline 1979 & 0.162 & -0.143 & 0.305 \\
\hline 1980 & 0.137 & -0.221 & 0.358 \\
\hline 1981 & 0.000 & -0.249 & 0.249 \\
\hline 1982 & -0.163 & -0.169 & 0.006 \\
\hline 1983 & -0.120 & -0.262 & 0.142 \\
\hline 1984 & -0.013 & -0.125 & 0.112 \\
\hline 1985 & 0.039 & -0.110 & 0.149 \\
\hline 1986 & 0.038 & -0.073 & 0.111 \\
\hline 1987 & -0.071 & -0.078 & 0.007 \\
\hline 1988 & -0.014 & -0.078 & 0.064 \\
\hline 1989 & -0.035 & -0.087 & 0.052 \\
\hline 1990 & 0.116 & -0.010 & 0.126 \\
\hline 1991 & 0.195 & -0.046 & 0.241 \\
\hline 1992 & 0.116 & -0.053 & 0.169 \\
\hline 1993 & 0.147 & -0.115 & 0.262 \\
\hline 1994 & 0.135 & -0.075 & 0.210 \\
\hline 1995 & 0.198 & -0.151 & 0.349 \\
\hline 1996 & 0.170 & -0.094 & 0.264 \\
\hline 1997 & 0.147 & -0.048 & 0.195 \\
\hline 1998 & 0.083 & 0.014 & 0.069 \\
\hline 1999 & -0.105 & -0.332 & 0.227 \\
\hline 2000 & -0.060 & -0.206 & 0.146 \\
\hline 2001 & 0.231 & 0.024 & 0.207 \\
\hline 2002 & 0.204 & 0.032 & 0.171 \\
\hline 2003 & 0.311 & -0.012 & 0.323 \\
\hline 2004 & 0.158 & -0.029 & 0.187 \\
\hline 2005 & 0.067 & -0.178 & 0.245 \\
\hline 2006 & 0.040 & -0.114 & 0.154 \\
\hline 2007 & -0.166 & -0.095 & -0.071 \\
\hline 2008 & 0.184 & 0.014 & 0.170 \\
\hline 2009 & 0.275 & 0.004 & 0.271 \\
\hline 2010 & 0.161 & -0.052 & 0.213 \\
\hline Mean & 0.052 & -0.049 & 0.102 \\
\hline$S D$ & 0.143 & 0.132 & 0.206 \\
\hline
\end{tabular}


Table 2: Logit Regression on decision to pay dividends/repurchase shares

This table shows results of logit regressions to model the choice to repurchase shares and to pay dividends. The dependent variable Repurchaser takes a value of 1 if the firm is classified as a repurchaser for a particular year and zero otherwise. The dependent variable Dividend Payer takes a value of 1 if the firm is classified as a dividend payer in a particular year and zero otherwise. Repurchase Yield and Dividend Yield are the dollar amounts spent on repurchases and dividends, respectively, scaled by the market value of equity. Dollar amounts spent on repurchases are calculated using Purchase of Common and Preferred Stock (Compustat data PRSTKC) after adjusting for the decrease in Preferred Stock Redemption Value (PSTKRV) from the year before. Dollar amounts spent on dividends are calculated using the value of common dividends $(D V C)$. A firm is classified as a dividend payer if the dollar amount spent on dividends is positive. The Repurchaser classification and the Difference Premium are as defined in Table 1. LnAssets is the natural logarithm of the book value of total assets (AT). Debt is the value of long-term debt (DLTT), scaled by total assets. Cash is the value of cash and cash equivalents $(\mathrm{CHE})$ held by a firm, scaled by total assets. $F C F$ is the free cash flow, defined as the gross operating income (OIBDP) minus the sum of depreciation $(D P)$, tax payments (TXT), interest expenses (XINT), and dividends (sum of DVP and DVC) scaled by total assets. ROA is the return on assets, calculated as the value of the operating income of the firm $(O I B D P)$ scaled by total assets. Std. Dev. FCF is the standard deviation in the FCF value over the last three years. Return is the return on the stock price of the firm in the fiscal year. $M / B$ is the market-to-book ratio measured as in Fama and French (2001). NYP is the New York Stock Exchange (NYSE) market capitalization percentile, i.e., the fraction of NYSE firms having equal or smaller capitalization. Idiosyncratic Risk is the standard deviation of residuals from a regression of the firm's daily excess stock returns (raw returns less the risk-free rate) on the market factor (i.e., the value-weighted market return from the Center for Research in Security Prices (CRSP) less the riskfree rate). Systematic Risk is the standard deviation of the predicted value from the idiosyncratic risk calculation. NYP, Systematic and Idiosyncratic risk variables are as defined in Hoberg and Prabhala (2009). Tax is the difference between the highest prevalent rate in income tax over capital gains tax. All independent variables are calculated at the end of the prior fiscal year (and hence represented with a subscript of $t-1$ ). Time periods for samples used in the individual specifications are as mentioned. Specifications 1 through 4 show results of logit regressions. Specification 5 shows results of a logit regression with firm fixed effects. Reported $p$-values are based on robust standard errors (also clustered by firm for specifications 1 through 4 ). ***, **, and * indicate significance at the $0.01,0.05$, and 0.10 levels, respectively. 
Dependent Variable:

Repurchase Yield ${ }_{t-1}$

Dividend Yield $_{t-1}$

LnAssets $_{t-1}$

$\operatorname{Debt}_{t-1}$

Cash $_{t-1}$

$F C F_{t-1}$

$R O A_{t-1}$

Std. dev $F C F_{t-1}$

Return $_{t-1}$

$M / B_{t-1}$

$N Y P_{t-1}$

Idiosyncratic Risk $_{t-1}$

Systematic Risk

$\operatorname{Tax}_{t-1}$

Difference Premium $_{t-1}$

Constant

Firm Fixed Effects

Observations

Pseudo R-Squared
Dividend

\begin{tabular}{|c|c|c|c|c|}
\hline Payer & Repurchaser & Repurchaser & Repurchaser & Repurchaser \\
\hline $\begin{array}{c}1972-2010 \\
(1)\end{array}$ & $\begin{array}{c}1972-2010 \\
(2)\end{array}$ & $\begin{array}{c}1983-2010 \\
(3)\end{array}$ & $\begin{array}{c}1972-2006 \\
(4)\end{array}$ & $\begin{array}{c}1972-2010 \\
(5)\end{array}$ \\
\hline $\begin{array}{l}-1.015 \\
(0.173)\end{array}$ & $\begin{array}{c}25.267 * * * \\
(0.000)\end{array}$ & $\begin{array}{c}23.097 * * * \\
(0.000)\end{array}$ & $\begin{array}{c}28.292 * * * \\
(0.000)\end{array}$ & $\begin{array}{c}6.344 * * * \\
(0.000)\end{array}$ \\
\hline $\begin{array}{c}17.723 * * * \\
(0.000)\end{array}$ & $\begin{array}{c}-0.144 * * * \\
(0.000)\end{array}$ & $\begin{array}{l}-0.059 * \\
(0.085)\end{array}$ & $\begin{array}{c}-0.139 * * * \\
(0.000)\end{array}$ & $\begin{array}{c}-0.116^{* * * *} \\
(0.002)\end{array}$ \\
\hline $\begin{array}{c}0.005 \\
(0.839)\end{array}$ & $\begin{array}{c}0.001 \\
(0.939)\end{array}$ & $\begin{array}{c}-0.086 * * * \\
(0.000)\end{array}$ & $\begin{array}{l}-0.026^{*} \\
(0.099)\end{array}$ & $\begin{array}{c}0.573 * * * \\
(0.000)\end{array}$ \\
\hline $\begin{array}{c}-0.424 * * * \\
(0.006)\end{array}$ & $\begin{array}{l}-0.134 \\
(0.139)\end{array}$ & $\begin{array}{l}-0.172 * \\
(0.080)\end{array}$ & $\begin{array}{l}-0.085 \\
(0.365)\end{array}$ & $\begin{array}{c}-1.799 * * * \\
(0.000)\end{array}$ \\
\hline $\begin{array}{l}-0.031 \\
(0.856)\end{array}$ & $\begin{array}{c}0.835^{* * *} \\
(0.000)\end{array}$ & $\begin{array}{c}0.779 * * * \\
(0.000)\end{array}$ & $\begin{array}{c}0.808 * * * \\
(0.000)\end{array}$ & $\begin{array}{c}1.457 * * * \\
(0.000)\end{array}$ \\
\hline $\begin{array}{c}4.223 * * * \\
(0.000)\end{array}$ & $\begin{array}{c}-0.553 * * \\
(0.011)\end{array}$ & $\begin{array}{c}-0.536 * * \\
(0.034)\end{array}$ & $\begin{array}{c}-0.633 * * * \\
(0.004)\end{array}$ & $\begin{array}{l}-0.083 \\
(0.768)\end{array}$ \\
\hline $\begin{array}{c}2.637 * * * \\
(0.000)\end{array}$ & $\begin{array}{c}3.182 * * * \\
(0.000)\end{array}$ & $\begin{array}{c}3.208 * * * \\
(0.000)\end{array}$ & $\begin{array}{c}3.273 * * * \\
(0.000)\end{array}$ & $\begin{array}{c}1.768 * * * \\
(0.000)\end{array}$ \\
\hline $\begin{array}{c}-10.932 * * * \\
(0.000)\end{array}$ & $\begin{array}{c}-0.734 * * * \\
(0.001)\end{array}$ & $\begin{array}{c}-0.940 * * * \\
(0.000)\end{array}$ & $\begin{array}{c}-0.845^{* * *} * \\
(0.000)\end{array}$ & $\begin{array}{c}-0.827 * * * \\
(0.002)\end{array}$ \\
\hline $\begin{array}{c}0.037 * * * \\
(0.000)\end{array}$ & $\begin{array}{c}-0.035 * * * \\
(0.003)\end{array}$ & $\begin{array}{c}-0.024 * * \\
(0.025)\end{array}$ & $\begin{array}{c}-0.034 * * * \\
(0.005)\end{array}$ & $\begin{array}{c}-0.035 * * * \\
(0.001)\end{array}$ \\
\hline $\begin{array}{c}-0.206 * * * \\
(0.000)\end{array}$ & $\begin{array}{c}-0.064 * * * \\
(0.000)\end{array}$ & $\begin{array}{c}-0.109 * * * \\
(0.000)\end{array}$ & $\begin{array}{c}-0.068 * * * \\
(0.000)\end{array}$ & $\begin{array}{c}-0.032 * * * \\
(0.008)\end{array}$ \\
\hline $\begin{array}{c}0.010 * * * \\
(0.000)\end{array}$ & $\begin{array}{c}0.006^{* * * *} \\
(0.000)\end{array}$ & $\begin{array}{c}0.013 * * * \\
(0.000)\end{array}$ & $\begin{array}{c}0.008 * * * \\
(0.000)\end{array}$ & $\begin{array}{c}0.001 \\
(0.355)\end{array}$ \\
\hline $\begin{array}{c}-24.110 * * * \\
(0.000)\end{array}$ & $\begin{array}{c}-7.446 * * * \\
(0.000)\end{array}$ & $\begin{array}{c}-7.282 * * * \\
(0.000)\end{array}$ & $\begin{array}{c}-6.906 * * * \\
(0.000)\end{array}$ & $\begin{array}{c}-2.514 * * * \\
(0.003)\end{array}$ \\
\hline $\begin{array}{c}-27.921 * * * \\
(0.000)\end{array}$ & $\begin{array}{c}6.681 * * * \\
(0.001)\end{array}$ & $\begin{array}{c}10.133 * * * \\
(0.000)\end{array}$ & $\begin{array}{c}1.384 \\
(0.551)\end{array}$ & $\begin{array}{c}8.177 * * * \\
(0.000)\end{array}$ \\
\hline $\begin{array}{c}1.366^{* * * *} \\
(0.000)\end{array}$ & $\begin{array}{c}-0.804 * * * \\
(0.000)\end{array}$ & $\begin{array}{c}0.931 * * * \\
(0.000)\end{array}$ & $\begin{array}{c}-0.806 * * * \\
(0.000)\end{array}$ & $\begin{array}{l}-0.072 \\
(0.537)\end{array}$ \\
\hline $\begin{array}{c}-1.403 * * * \\
(0.000)\end{array}$ & $\begin{array}{c}0.592 * * * \\
(0.000)\end{array}$ & $\begin{array}{c}0.723 * * * \\
(0.000)\end{array}$ & $\begin{array}{c}0.642 * * * \\
(0.000)\end{array}$ & $\begin{array}{c}0.218 * * * \\
(0.002)\end{array}$ \\
\hline $\begin{array}{c}-1.150 * * * \\
(0.000)\end{array}$ & $\begin{array}{c}-1.413 * * * \\
(0.000)\end{array}$ & $\begin{array}{c}-1.376 * * * \\
(0.000)\end{array}$ & $\begin{array}{c}-1.371 * * * \\
(0.000)\end{array}$ & - \\
\hline No & No & No & No & Yes \\
\hline 85,678 & 85,678 & 62,351 & 80,683 & 54,678 \\
\hline 0.720 & 0.079 & 0.093 & 0.082 & 0.056 \\
\hline
\end{tabular}


Table 3: Propensity to repurchase

This table shows results for the second of a two-stage regression of repurchasing activity on firm characteristics and the premiums. The sample period is from 1972 to 2010 . The first stage is a set of FamaMacBeth logit regressions modeling the decision to repurchase shares using firm characteristics as controls, per the following equation:

$\operatorname{Pr}\left(\right.$ Repurchaser $\left._{\mathrm{it}}=1\right)=\operatorname{logit}\left(\mathrm{a}+\mathrm{bNYP}_{\mathrm{it}}+\mathrm{c} \frac{\mathrm{M}}{\mathrm{B}_{\mathrm{it}}}+\mathrm{d} \frac{\mathrm{dA}}{\mathrm{A}_{\mathrm{it}}}+\mathrm{e} \frac{\mathrm{E}}{\mathrm{A}_{\mathrm{it}}}\right)+\mathrm{u}_{\mathrm{it}}$

where NYP is the NYSE market capitalization percentile. $M / B$ is measured as in Fama and French (2001). Growth in book assets $(d A / A)$ is calculated as the change in asset size between year $t-1$ and $t$, scaled by assets. Profitability $(E / A)$ is the earnings before extraordinary items (Compustat data $I B$ ) plus interest expenses (XINT) plus income statement deferred taxes (TXDI) divided by book assets. Yearly values of coefficients and the explanatory variables are used to predict the probability of repurchasing shares. The error term $u$ is the prediction error (actual policy minus predicted policy) or the residual propensity to repurchase shares for a given firm in the year. The residual $u_{i t}$ are summed by year, and then divided by the number of firms in the sample for that year $t$ to get the average annual prediction errors or the "propensity to repurchase."

In the second stage, the average annual "propensity to repurchase" $(P T R)$ is regressed on the relevant premium:

$$
\mathrm{PTR}_{\mathrm{t}}=\mathrm{f}+\mathrm{gP}_{\mathrm{t}-1}+\mathrm{v}_{\mathrm{t}} ; \text { where } \mathrm{PTR}_{\mathrm{t}}=\frac{1}{\mathrm{~N}} \sum_{\mathrm{i}} \mathrm{u}_{\mathrm{it}}
$$

$\mathrm{P}_{\mathrm{t}-1}$ represents the one-year lagged value of the premium variable listed in the (second-stage) result. Running the first-stage regression with "Fama-French" controls implies running the first-stage FamaMacBeth regressions using the four variables shown above, (i.e., NYP, M/B, dA/A, and E/A) as controls. Running the first-stage regression with "Fama-French + Risk" controls implies running the first-stage Fama-MacBeth regressions using Idiosyncratic Risk, Systematic Risk, and the four variables (i.e., Systematic Risk, Idiosyncratic Risk, NYP, M/B, dA/A and E/A) as controls. Systematic Risk and Idiosyncratic Risk are as described in Table 2. Dividend Premium and Difference Premium variables are as described in Table 1.

Panel A shows results when the first-stage regression is run using all sample firms between 1972 and 2010. Panel B shows the results when the sample is restricted to the dividend-paying firms in the same time period. For this, the first-stage regression is run for the choice to repurchase shares (but now only for dividend-paying firms). The second stage remains the same. Reported $p$-values are based on robust standard errors. ${ }^{* * *}, * *$, and $*$ indicate significance at the $0.01,0.05$, and 0.10 levels, respectively. 
Panel A. All firms in sample

First stage independent variables:

Second stage dependent variable:

Difference Premium $_{t-1}$

Dividend Premium $_{t-1}$

\begin{tabular}{|c|c|c|c|}
\hline \multicolumn{2}{|c|}{ Fama-French } & \multicolumn{2}{|c|}{ Fama-French + Risk } \\
\hline \multicolumn{4}{|c|}{ PTR } \\
\hline (1) & (2) & $(3)$ & (4) \\
\hline $\begin{array}{c}0.111 * * \\
(0.040)\end{array}$ & & $\begin{array}{c}0.110 * * \\
(0.049)\end{array}$ & \\
\hline & $\begin{array}{l}-0.152 * \\
(0.071)\end{array}$ & & $\begin{array}{l}-0.150 \\
(0.185)\end{array}$ \\
\hline 38 & 38 & 38 & 38 \\
\hline 0.112 & 0.088 & 0.103 & 0.080 \\
\hline
\end{tabular}

Panel B. Dividend-paying firms

First stage independent variables:

Second stage dependent variable:

Difference Premium Pr-1 $_{1}$

Dividend Premium $_{t-1}$

Observations

$R$-Squared

\begin{tabular}{|c|c|c|c|}
\hline \multicolumn{2}{|c|}{ Fama-French } & \multicolumn{2}{|c|}{ Fama-French + Risk } \\
\hline \multicolumn{4}{|c|}{ PTR } \\
\hline$(1)$ & $(2)$ & $(3)$ & $(4)$ \\
\hline $\begin{array}{c}0.186 * * \\
(0.019)\end{array}$ & & $\begin{array}{c}0.179 * * \\
(0.024)\end{array}$ & \\
\hline & $\begin{array}{c}-0.188 \\
(0.131)\end{array}$ & & $\begin{array}{l}-0.182 \\
(0.146)\end{array}$ \\
\hline 38 & 38 & 38 & 38 \\
\hline 0.144 & 0.062 & 0.133 & 0.058 \\
\hline
\end{tabular}


Table 4: Lintner model residual dividend error

This table shows results of regressions explaining deviation from predicted dividend payment behavior. The dependent variable is the residual dividend error (Error), calculated following the Lintner (1956) model. Error is given by

$$
\operatorname{Error}_{i, t}=\left[\Delta D I V_{i, t}-\left(\beta_{i, 1}+\beta_{i, 2,} \operatorname{EARN}_{i, t}+\beta_{i, 3} D I V_{i, t-1}\right)\right] / M V_{i, t-1} .
$$

For a firm $i$ in year $t, D I V$ is the dividend (Compustat data $D V C$ ), $\triangle D I V$ is the actual change in dividends in year $t, E A R N$ is the earnings before extraordinary items $(I B)$, and $M V$ is the market value of equity (calculated as PRCC_C times CSHO). $\beta_{1, \mathrm{i}}, \beta_{2, \mathrm{i}}$, and $\beta_{3, \mathrm{i}}$ are the model parameters estimated for each firm $i$ over the period 1971-1990. These parameters are used to find the predicted change in dividends and then compared to the actual change to get the Error, using the equation above, for the period 1991-2010. To be included in the sample, firms must have paid dividends in at least 20 years and repurchased shares in 20 years (not necessarily both in the same year) over the period 1971-2010. Non-operating Income is the nonoperating income before depreciation (NOPI) scaled by total assets. LnMVE is the natural logarithm of the MV. Difference Premium, Repurchase Yield, Debt, ROA, NYP, Idiosyncratic Risk, and Systematic Risk are as described in Tables 1 and 2. Std. dev ROA is the standard deviation of ROA, calculated using the last three years. All independent variables are calculated at end of fiscal year $t-l$. All specifications use dummy variables to control for the 48 Fama and French (1997) industries. Reported $p$-values are based on robust standard errors clustered by firm. $* * * * *$, and * indicate significance at the $0.01,0.05$, and 0.10 levels, respectively.

\begin{tabular}{|c|c|c|c|}
\hline \multirow[t]{2}{*}{ Dependent Variable: } & \multicolumn{3}{|c|}{ Error } \\
\hline & $(1)$ & $(2)$ & $(3)$ \\
\hline \multirow[t]{2}{*}{ Repurchase Yield $_{t-1}$} & $-0.021 * *$ & $-0.019 *$ & $-0.021 * *$ \\
\hline & $(0.038)$ & $(0.052)$ & $(0.033)$ \\
\hline \multirow[t]{2}{*}{$\operatorname{Debt}_{t-1}$} & $-0.002 * *$ & $-0.002 *$ & $-0.002 *$ \\
\hline & $(0.027)$ & $(0.083)$ & $(0.077)$ \\
\hline \multirow[t]{2}{*}{ Non-operating Income $_{t-1}$} & 0.006 & 0.002 & 0.001 \\
\hline & $(0.252)$ & $(0.748)$ & $(0.807)$ \\
\hline \multirow[t]{2}{*}{ Std. dev $R O A_{t-1}$} & -0.005 & 0.001 & 0.001 \\
\hline & $(0.570)$ & $(0.911)$ & $(0.929)$ \\
\hline \multirow[t]{2}{*}{$R O A_{t-1}$} & -0.002 & -0.002 & -0.002 \\
\hline & $(0.337)$ & $(0.185)$ & $(0.165)$ \\
\hline \multirow[t]{2}{*}{$L n M V E_{t-1}$} & $0.000 * * *$ & 0.000 & 0.000 \\
\hline & $(0.002)$ & $(0.321)$ & $(0.165)$ \\
\hline \multirow[t]{2}{*}{$N Y P_{t-1}$} & & 0.000 & 0.000 \\
\hline & & $(0.757)$ & $(0.976)$ \\
\hline \multirow[t]{2}{*}{ Idiosyncratic Risk $_{t-1}$} & & $-0.103^{*}$ & $-0.104 *$ \\
\hline & & $(0.085)$ & $(0.080)$ \\
\hline \multirow[t]{2}{*}{ Systematic Risk $_{t-1}$} & & -0.005 & -0.015 \\
\hline & & $(0.906)$ & $(0.689)$ \\
\hline \multirow[t]{2}{*}{ Difference Premium Pr-1 $_{1}$} & & & $-0.003 *$ \\
\hline & & & $(0.086)$ \\
\hline \multirow[t]{2}{*}{ Constant } & $-0.001 *$ & 0.001 & 0.002 \\
\hline & $(0.052)$ & $(0.475)$ & $(0.331)$ \\
\hline Observations & 3,585 & 3,561 & 3,561 \\
\hline Adj R-Squared & 0.009 & 0.019 & 0.020 \\
\hline
\end{tabular}


Table 5: Changes in total payout and repurchases

This table shows the results of ordinary least squares (OLS) and tobit regressions explaining the fraction of the additional total payout of firms that is used for repurchasing shares. The dependent variable is the change in the dollar amount of repurchases divided by the change in total payout, between year $t-1$ and year $t$. Total payout is defined as the sum of share repurchases and dividends. Specifications 1 and 2 show results for the OLS regressions using data from 1972-2010 and from 1983-2010, respectively. Specification 3 shows results for a tobit regression using data from 1972-2010. $\triangle R O A$ is the one-year change in ROA. All other variables are as described in Tables 1 and 2. All specifications use dummy variables to control for the 48 Fama and French (1997) industries. Reported $p$-values are based on robust standard errors (also clustered by firm for specifications 1 and 2 ). $* * *, * *$, and $*$ indicate significance at the $0.01,0.05$, and 0.10 levels, respectively.

Dependent Variable:

ARepurchase/(4 Total Payout)

\begin{tabular}{|c|c|c|}
\hline OLS & OLS & Tobit \\
\hline $1972-2010$ & $1983-2010$ & $1972-2010$ \\
\hline (1) & (2) & (3) \\
\hline$-0.617 * * *$ & $-0.112 * *$ & $-0.592 * * *$ \\
\hline$(0.000)$ & $(0.017)$ & $(0.000)$ \\
\hline $0.032 * * *$ & 0.007 & $0.033^{* * *}$ \\
\hline$(0.000)$ & $(0.261)$ & $(0.000)$ \\
\hline-0.024 & -0.016 & -0.021 \\
\hline$(0.422)$ & $(0.630)$ & (0.308) \\
\hline $0.120 * * *$ & $0.074 * *$ & $0.080 * * *$ \\
\hline$(0.000)$ & $(0.012)$ & $(0.000)$ \\
\hline $0.942 * * *$ & $0.843 * * *$ & $0.661 * * *$ \\
\hline$(0.000)$ & $(0.000)$ & $(0.000)$ \\
\hline$-0.749 * * *$ & $-0.663 * * *$ & $-0.523 * * *$ \\
\hline$(0.000)$ & $(0.000)$ & $(0.000)$ \\
\hline $0.696^{* * *}$ & $0.590 * * *$ & $0.410 * * *$ \\
\hline$(0.000)$ & $(0.000)$ & $(0.000)$ \\
\hline-0.000 & 0.002 & -0.000 \\
\hline$(0.804)$ & $(0.367)$ & $(0.810)$ \\
\hline $0.022 * * *$ & $0.010^{* * * *}$ & $0.017^{* * *}$ \\
\hline$(0.000)$ & $(0.005)$ & $(0.000)$ \\
\hline$-0.004 * * *$ & $-0.003^{* * *}$ & $-0.003 * * *$ \\
\hline$(0.000)$ & $(0.000)$ & $(0.000)$ \\
\hline $2.543 * * *$ & $1.810 * * *$ & $1.524 * * *$ \\
\hline$(0.000)$ & $(0.000)$ & $(0.000)$ \\
\hline $5.507 * * *$ & $6.545^{* * *}$ & $4.721 * * *$ \\
\hline$(0.000)$ & $(0.000)$ & $(0.000)$ \\
\hline-0.020 & $-0.052^{*}$ & -0.043 \\
\hline$(0.504)$ & $(0.074)$ & $(0.134)$ \\
\hline $0.192 * * *$ & $0.199 * * *$ & $0.184 * * *$ \\
\hline$(0.000)$ & $(0.000)$ & $(0.000)$ \\
\hline $0.477 * * *$ & $0.574 * * *$ & $0.734 * * *$ \\
\hline$(0.000)$ & $(0.000)$ & $(0.000)$ \\
\hline 59,913 & 42,144 & 59,913 \\
\hline 0.084 & 0.060 & 0.048 \\
\hline
\end{tabular}




\section{Table 6: Market Reaction to dividend changes}

This table shows the three-day cumulative abnormal return (CAR) for announcements of a change in the level of regular quarterly cash dividend paid by firms under certain situations. CARs are calculated using a market model return in which parameters are estimated using a 255-trading-day window, ending 46 days prior to the change in dividend announcement and requiring at least 100 observations. Center for Research in Securities Prices (CRSP) value-weighted portfolio is used as the benchmark for market returns. Difference Premium is as described in Table 1. Announcements of changes in the regular cash dividend to be paid to common shareholders are obtained from the CRSP database for the period of 1972-2010. Changes in dividend announcements are put into two groups. First group includes those where the announcement leads to an increase in dividends (between 5 and $25 \%$ of the last dividend) when the difference premium decreased. These are in the left panel. The second group includes the announcements leading to reductions in dividends (between 5 and $25 \%$ of the last dividend) when the difference premium increased. These are in the right panel. These groups are created to see how the market reaction lines up with the action suggested by the catering hypothesis. The Repurchaser column refers to firms within a group that have repurchased shares worth more than $1 \%$ of the market value of equity within one fiscal year prior to the announcement of the dividend change. Non-repurchaser refers to firms that do not meet the repurchaser criterion. Difference shows the difference in CARs between the Repurchaser and the Nonrepurchaser category within the group. Means and medians of the CAR are shown. Significance levels of means (medians) are tested to see if they are significantly different from zero using a two-tailed $t$-test (Wilcoxon Rank-sum test). Then the difference between the means (medians) is tested using a two-tailed $t$ test (Wilcoxon Rank-sum test). ***, **, and * indicate significance at the $0.01,0.05$, and 0.10 levels, respectively.

\begin{tabular}{lccc|ccc} 
& \multicolumn{2}{c|}{$\begin{array}{c}\text { Dividend increase anouncements } \\
\text { when Difference Premium decreased }\end{array}$} & \multicolumn{2}{c}{$\begin{array}{c}\text { Dividend decrease announcements } \\
\text { when Difference Premium increased }\end{array}$} \\
\cline { 2 - 6 } & Repurchaser & Non-repurchaser & Difference & Repurchaser & Non-repurchaser & Difference \\
\cline { 2 - 6 } Mean & $0.893^{* * *}$ & $1.052^{* * *}$ & $-0.159^{*}$ & -0.103 & $-0.705^{* * *}$ & $0.602 * *$ \\
Median & $0.723 * * *$ & $0.796^{* * * *}$ & $-0.074 *$ & $0.238^{*}$ & $-0.214 * * *$ & $0.452^{* *}$ \\
Observations & 2,326 & 5,287 & & 557 & 1,463 & \\
\hline
\end{tabular}


Table 7: Multivariate tests on market response to dividend changes

This table shows results of regressions explaining the market reaction to announcements of dividend changes. Announcements of changes in the regular cash dividend to be paid to common shareholders are obtained from the CRSP database for the period 1972-2010. The dependent variable is CAR, as described in Table 6. The first three specifications include announcements that led to a decrease in the regular cash dividend to be paid to common shareholders. Specifications 4-6 include announcements that led to an increase in the cash dividend amount to be paid to common shareholders. To be included in the sample, the dividend changes have to be between 5 and $25 \%$, relative to the previous dividend. Change Percent is the absolute value of the percentage change in the dividend. All other variables are as described in Tables 1, 2, 4, and 5. Following Grullon and Michaely (2002), ROA has been truncated at the first and the $99^{\text {th }}$ percentiles, and Dividend Yield has been truncated at the $99^{\text {th }}$ percentile. Reported $p$-values are based on robust standard errors clustered by firm. $* * *, * *$, and $*$ indicate significance at the $0.01,0.05$, and 0.10 levels, respectively.

Dependent Variable:

\begin{tabular}{|c|c|c|c|c|c|}
\hline \multicolumn{6}{|c|}{ CAR } \\
\hline \multicolumn{3}{|c|}{ Dividend decrease } & \multicolumn{3}{|c|}{ Dividend increase } \\
\hline$(1)$ & $(2)$ & (3) & (4) & (5) & $(6)$ \\
\hline $\begin{array}{c}0.007 * * \\
(0.034)\end{array}$ & $\begin{array}{c}0.005 \\
(0.146)\end{array}$ & $\begin{array}{c}0.004 \\
(0.194)\end{array}$ & $\begin{array}{l}-0.001 * \\
(0.084)\end{array}$ & $\begin{array}{l}-0.000 \\
(0.794)\end{array}$ & $\begin{array}{c}0.001 \\
(0.706)\end{array}$ \\
\hline $0.052 * * *$ & $0.047 * * *$ & $0.047 * * *$ & $0.036^{*}$ & $0.037 * *$ & $0.039^{* *}$ \\
\hline$(0.002)$ & $(0.001)$ & $(0.001)$ & $(0.051)$ & $(0.039)$ & $(0.034)$ \\
\hline $\begin{array}{l}0.002 * \\
(0.081)\end{array}$ & $\begin{array}{l}-0.002 \\
(0.141)\end{array}$ & $\begin{array}{l}-0.003^{*} \\
(0.074)\end{array}$ & $\begin{array}{c}-0.003 * * * \\
(0.000)\end{array}$ & $\begin{array}{c}-0.002 * * * \\
(0.007)\end{array}$ & $\begin{array}{l}-0.001 \\
(0.178)\end{array}$ \\
\hline $\begin{array}{c}0.000 \\
(0.921)\end{array}$ & $\begin{array}{l}-0.001 \\
(0.735)\end{array}$ & $\begin{array}{c}-0.001 \\
(0.881)\end{array}$ & $\begin{array}{c}0.004 * * * \\
(0.000)\end{array}$ & $\begin{array}{c}0.005^{* * *} * \\
(0.000)\end{array}$ & $\begin{array}{c}0.004 * * * \\
(0.000)\end{array}$ \\
\hline $0.044 * *$ & 0.033 & 0.030 & -0.003 & -0.003 & -0.005 \\
\hline \multirow[t]{5}{*}{$(0.037)$} & $(0.139)$ & $(0.182)$ & $(0.414)$ & $(0.462)$ & $(0.236)$ \\
\hline & $\begin{array}{c}0.000 * * * \\
(0.002)\end{array}$ & $\begin{array}{c}0.000 * * * \\
(0.001)\end{array}$ & & $\begin{array}{c}-0.000 * * \\
(0.013)\end{array}$ & $\begin{array}{c}-0.000 * * * \\
(0.002)\end{array}$ \\
\hline & $\begin{array}{l}-0.183 \\
(0.612)\end{array}$ & $\begin{array}{l}-0.159 \\
(0.643)\end{array}$ & & $\begin{array}{l}-0.009 \\
(0.940)\end{array}$ & $\begin{array}{l}-0.014 \\
(0.913)\end{array}$ \\
\hline & $\begin{array}{l}-0.228 \\
(0.506)\end{array}$ & $\begin{array}{l}-0.286 \\
(0.362)\end{array}$ & & $\begin{array}{c}0.117 \\
(0.443)\end{array}$ & $\begin{array}{c}0.054 \\
(0.730)\end{array}$ \\
\hline & & $\begin{array}{c}0.052 * * \\
(0.022)\end{array}$ & & & $\begin{array}{c}-0.011 * * \\
(0.012)\end{array}$ \\
\hline 0.006 & 0.018 & 0.010 & $0.020 * * *$ & $0.018 * * *$ & $0.014 * *$ \\
\hline$(0.479)$ & $(0.105)$ & (0.364) & $(0.000)$ & $(0.004)$ & $(0.011)$ \\
\hline 1,947 & 1,947 & 1,947 & 5,816 & 5,816 & 5,816 \\
\hline 0.026 & 0.040 & 0.053 & 0.015 & 0.016 & 0.019 \\
\hline
\end{tabular}

